Mongolian Academy of Sciences
Mongolian Journal of Chemistry
Institute of Chemistry \& Chemical Technology

\title{
Phytochemical study on Berberis sibirica Pall.
}

\author{
A.Solongo', R. Istatkova ${ }^{2}$, S. Philipov ${ }^{2}$, S.Javzan ${ }^{1}$, D.Selenge ${ }^{1}$ \\ Institute of Chemistry and Chemical Technology, Mongolian Academy of Sciences, \\ Ulaanbaatar 210351, Mongolia \\ ${ }^{2}$ Institute of Organic Chemistry with Centre of Phytochemistry, Bulgarian Academy of Sciences, \\ Acad. G. Bonchev bl.9, 1113 Sofia, Bulgaria \\ solongoamgalan@yahoo.com
}

\begin{abstract}
From the aerial parts (700g) of berberis sibirica pall. 6 isoquinoline alkaloids of protoberberine, protopine, benzophenantridine and proaporphine type were isolated. The known alkaloids (-)-tetrahydropseudocoptisine, pseudoprotopine, (+)-chelidonine and (+)-glaziovine are new for the family berberidaceae. from the aerial part ii $(3.9 \mathrm{~kg}) 14$ isoquinoline alkaloids of aporphine, proaporphine, protoberberine, protopine, benzylisoquinoline, bisbenzylisoquinoline, proaporphine-benzylisoquinoline and simple isoquinolin type were isolated and identified. The aporphine alkaloid 1-o-methylisotebaidine and simple isoquinoline dehydrocorypalline have been found for the first time in the family of berberidaceae. From the roots of $b$. sibirica 10 isoquinoline alkaloids of protoberberine, benzylisoquinoline, bisbenzylisoquinoline, aporphinebenzylisoquinoline and proaporphine-benzylisoquinoline type were isolated. 1,10-di-omethylpakistanine has been reported for the first time as a natural alkaloid. The known alkaloids (-) -isothalidezine and (+)-armepavine have been found for the first time in the family berberidaceae. all structures were determined by physical and spectral data.
\end{abstract}

Key words: berberis sibirica pall., 21 bisoquinoline alkaloids, 1,10-di-o-methylpakistanine

\section{Introduction}

B erberidaceae is a large family of flowering plants divided into 15 genera. The family contains about 570 species, of which the majority (about 450) belongs to the biggest genus in this family Berberis L. [ $\left.{ }^{1}\right]$. The Berberis species have been deeply investigated because of biological active compounds, namely isoquinoline alkaloids, containing inside $\left.{ }^{2,3}\right]$. The genus Berberis is represented by two species in Mongolian flora. Berberis sibirica Pall. is wide spread in Central and North Mongolia - Gobi and Altai regions. In the traditional medicine the species is used as antidote and antipyretic remedy, as well as for rheumatism and excessive menstruation $\left[{ }^{4}\right]$.

\section{Experimental}

Materials and methods. GENERAL. UV: SESIL CE 8020, MeOH. IR: Bruker IFS113V, KBr. MS: Hewlett Packard MSD 5973, $70 \mathrm{eV} .{ }^{1} \mathrm{H}$ NMR, ${ }^{13} \mathrm{C}$ NMR and $2 \mathrm{D}$ experiments: Bruker DRX-250, in $\mathrm{CDCl}_{3}$, with TMS as internal standard. Optical rotation: Perkin-Elmer 241, MeOH. Vacuum liquid chromatography (VLC): silica gel (Merck, Kieselgel 60, 70-230 mesh). Column chromatography (CC): neutra alumina (Merck, Aluminiumoxid 90, act. II-III Brockmann, 70-230 mesh). PTLC: Kieselgel 
$\mathrm{GF}_{254}$. Visualization for TLC: Dragendorff's reagent.

Plant material. Berberis sibirica Pall. aerial part I (700 g) was collected in August 2003 during the time of fruiting near the lake "Terkhiin Tsagaan nuur", province Arkhangai, Central Mongolia. 700 gr plant material was not enough and we collected more plant material in 2005. The sample of aerial part II $(3.9 \mathrm{~kg})$ and roots $(2.2 \mathrm{~kg})$ were collected in August 2005 during the time flowering near Khorgo mountain in Arkhangai province. The plant materials were identified by prof. Ch. Sanchir, Institute of Botany, Mongolian Academy of Sciences and the voucher specimen is deposited in the Herbarium Fund of the same Institute.

Extraction and isolation. Air dried and aerial parts $(0.7 \mathrm{~kg}$ and $3.9 \mathrm{~kg})$ and roots $(2.2 \mathrm{~kg})$ were worked up separately, by the same manner. They were extracted exhaustively with $95 \% \mathrm{EtOH}$ at room temperature. The combined EtOH extracts were evaporated under reduced pressure, acidified with $5 \%$ $\mathrm{HCl}$ to $\mathrm{pH} \mathrm{1-2}$ and left overnight at room temperature. Insoluble non-alkaloid materials were removed by filtration and the filtrate was subjected to n-hexane extraction to eliminate the rest of the non-alkaloid substances. Thus purified the acidic solution was made alkaline with $25 \% \mathrm{NH}_{4} \mathrm{OH}$ to $\mathrm{pH}$ 910 and extracted with $\mathrm{CHCl}_{3}$. The combined $\mathrm{CHCl}_{3}$ extracts were dried (anh. $\mathrm{Na}_{2} \mathrm{SO}_{4}$ ) and evaporated under reduced pressure to give crude mixtures of tertiary alkaloids - from the aerial part I Fraction A (1.29 g), aerial part II Fraction B (20.7 g) and from the roots Fraction R (13.91 g).

Fraction A was worked up by $\mathrm{CC}$ on neutra alumina, eluting with n-hexane:EtOAc of increasing polarity $(7: 1,5: 1,3: 1,1: 1$, EtOAc) and finally with pure $\mathrm{MeOH} .8$ combined alkaloid fractions (A1 - A8) enriched in individual alkaloids were obtained. A2 (5:1) was subjected to PTLC with mobile phase petroleum: $\mathrm{CHCl}_{3}: \mathrm{Me}_{2} \mathrm{CO}: \mathrm{MeOH} \quad(4: 4: 1: 1)$ and the alkaloid 7 (8.36 mg) was isolated. A3 (5:1) was subjected to PTLC with mobile phase petroleum: $\mathrm{CHCl}_{3}: \mathrm{Me}_{2} \mathrm{CO}: \mathrm{MeOH}$ (4:4:1:1) and the alkaloids 9 (2.37 $\mathrm{mg})$ and 14
(25.20 mg) were isolated. A4 (3:1) and A5 (3:1) were subjected to PTLC with mobile phase petroleum: $\mathrm{CHCl}_{3}: \mathrm{Me}_{2} \mathrm{CO}: \mathrm{MeOH}$ (4:8:1:2) and the alkaloids $\mathbf{6}(6.84 \mathrm{mg})$ and $\mathbf{1 0}$ (30.00 mg) were isolated, respectively. A7 and $\mathrm{A} 8$ (pure $\mathrm{MeOH}$ ) were subjected to PTLC with mobile phase petroleum: $\mathrm{CHCl}_{3}: \mathrm{Me}_{2} \mathrm{CO}: \mathrm{MeOH} \quad$ (2:8:1:3) and the alkaloid $1(5.00 \mathrm{mg})$ was isolated. A1 (7:1) and A6 (EtOAc) were in a small quantity (less than $10 \mathrm{mg}$ ) not enough for further isolation and characterization of pure compounds.

Fraction B was worked by VLC on silica gel, elutin with 1,2dichlorethane: $\mathrm{MeOH}$ of increasing polarity $(5: 1,3: 1$ and pure $\mathrm{MeOH})$ and six combined alkaloid fractions (BS1-BS6) were obtained. Fraction BS1 (15 g) was worked up by CC on neutral aluminia, eluting with nhexane:EtOAc of increasing polarity (5:1, $3: 1,1: 1$, EtOAc) and finally with pure $\mathrm{MeOH}$. Four combined fractions (BS1-1 BS1-4) enriched in individual alkaloids were obtained.

BS1-1 (3:1)(115.0 mg) was subjected to PTLC with Mph1and the alkaloids 12 (3.30 $\mathrm{mg})$ and $11(4.70 \mathrm{mg})$ were isolated. BS 1-2 (1:1) (1.9 g) was worked up by CC on neutral alumin, eluting with n-hexane:EtOokAc on increasing polarity (7:1, 5:1, 3:1, 1:1, EtOAc). Eight combined fractions (BS 1-2-1-BS 1-28) were obtained. BS 1-2-1 (7:1) (18.50 mg) was subjected to PTLC with Mph1 and the alkaloid 5 (10.0 mg) was isolated. BS 1-2-2 (5:1) was subjected to PTLC with Mph1 and the alkaloid $12 \mathrm{Mph} 1$ and the alkaloid 13 $(4.70 \mathrm{mg})$ and $9(3.80 \mathrm{mg})$ were isolated. BS $1-2-4(5: 1)(350.0 \mathrm{mg})(50.0 \mathrm{mg}$ from it) was subjected to PTLC with Mph1 and the alkaloid 11 (13.50 mg) was isolated. BS 1-2-5 (3:1) (61.70 mg) was subjected to PTLC with Mph1 and the alkaloids $11(8.40 \mathrm{mg})$ and $\mathbf{6}$ (19.80 mg) were isolated. BS 1-2-6 (3:1) (87.10 $\mathrm{mg}$ ) was subjected to PTLC with Mph2 and alkaloids 11 (5.20 mg), 6 (22.00 $\mathrm{mg})$ and $18(14.10 \mathrm{mg})$ were isolated. BS 1-27 (1:1) $(81.10 \mathrm{mg})$ was subjected to PTLC with $\mathrm{Mph} 2$ and the alkaloid 6 (30.0 mg) was isolated. BS 1-2-8 (EtOAc) (100.0 mg) was subjected to PTLC with Mph 11 and the alkaloid 6 (13.70 mg), 16 (7.40 mg) and 8 
(11.90 mg) were isolated. BS 1-3 (1:1 and EtOAc) $(650.0 \mathrm{mg})$ was worked up in the same manner, as S1-2 and four combined fractions (B.S1-3-1- B.S.1-3-4) were obtained. These fractions were separately subjected to PTLC with Mph1 and Mph2 and the same alkaloids, as in B.S.1-2 were isolated.

B.S.1-4 (MeOH) (2.0 g) (200.00 mg from it) was subjected to PTLC with Mph4 and the alkaloids $15(11.00 \mathrm{mg})$ and $\mathbf{1}(2.70 \mathrm{mg})$ were isolated.

Fraction B.S.2 (5.2 g) was worked up by CC on neutra alumina, eluting with n-hexane5 EtOAc of increasing polarity $(3: 1,1: 1$, EtOAc) and finally with pure $\mathrm{MeOH}$. Four combined fractions (B.S.2-1- B.S.2-4) enriched in individual alkaloids were obtained.

B.S.2-1 (1:1) (66.50 mg) was subjected to PTLC with Mph1 and the alkaloids 5 (2.7 $\mathrm{mg}$ ) and $6(3.60 \mathrm{mg})$ were isolated.

B.S.2-2 ( EtOAc) $(113.50 \mathrm{mg}$ ) was subjected to PTLC with Mph1 and the alkaloids 11 $(10.20 \mathrm{mg})$ and $6(5.60 \mathrm{mg})$ were isolated.

B.S.2-3 ( EtOAc) $(102.00 \mathrm{mg}$ ) was subjected to PTLC with Mph2 and the alkaloids 11 $(6.90 \mathrm{mg})$ and $16(11.50 \mathrm{mg})$ were isolated.

B.S.2-4 (MeOH) (2.0 g) (100.00 mg from it) was subjected to PTLC with Mph3 and the alkaloids $15(24 \mathrm{mg})$ and $\mathbf{3}(15.60 \mathrm{mg})$ were isolated.

Fraction B.S.3 (300.00 mg) was subjected to PTLC with Mph6 and the alkaloids 15 (25.40 $\mathrm{mg}), 3$ (17.30 mg), 2 (19.80 mg) and 4 $(11.10 \mathrm{mg})$ were isolated.

Fraction B.S.4 (25.00 mg) was subjected to PTLC with Mph3 and the alkaloid 3 (5.50 $\mathrm{mg}$ ) was isolated.

Fraction B.S.5 (100 mg) was subjected to PTLC with Mph3 and the alkaloids 15 (20.00 $\mathrm{mg}$ ) and $\mathbf{3}(9.00 \mathrm{mg})$ were isolated.

Fraction B.S.6 (50 mg) was subjected to PTLC with Mph3 and the alkaloids 15 (1.90 $\mathrm{mg}), 3(1.10 \mathrm{mg})$ and $2(2.00 \mathrm{mg})$ were isolated.

Fraction $\mathrm{R}$ was separatbed by VLC on silica gel, eluting with 1,2dichloroethane: $\mathrm{MeOH}$ of increasing polarity (5:1, 3:1, 1:1 and pure $\mathrm{MeOH})$ and combined alkaloid fractions (R1 - R6) were obtained. $\mathrm{R} 1$ was in a small quantity (less than $30 \mathrm{mg}$ ) not enough for further isolation and characterization of pure compounds. R2, R3 and $\mathrm{R} 4$ were separately worked up by $\mathrm{CC}$ on neutra alumina, eluting with n-hexane:EtOAc of increasing polarity $(7: 1,5: 1,3: 1,1: 1$, EtOAc) and finally with pure $\mathrm{MeOH}$ to afford fractions enriched in individual alkaloids. Elution of R2 with n-hexane:EtOAc (7:1, 5:1 and 3:1), followed by PTLC purification with petroleum: $\mathrm{CHCl}_{3}: \mathrm{Me}_{2} \mathrm{CO}: \mathrm{MeOH} \quad$ (4:4:1:1) yielded 5 (29.80 $\mathrm{mg}$ ) and 6 (29.30 mg). Further elution of R2 with pure $\mathrm{MeOH}$, followed by PTLC purification with petroleum: $\mathrm{CHCl}_{3}: \mathrm{Me}_{2} \mathrm{CO}: \mathrm{MeOH} \quad(2: 8: 1: 3)$ yielded 1 (13.37 mg). Alkaloid 1 was identified by TLC with standard and it was Berberine we did not isolate all of berberine alkaloid in pure. Elution of R3 with nhexane:EtOAc (3:1), followed by PTLC purification with petroleum: $\mathrm{CHCl}_{3}: \mathrm{Me}_{2} \mathrm{CO}: \mathrm{MeOH} \quad(4: 4: 1: 1)$ gave 18 (4.88 mg). Further elution of R3 with n-hexane:EtOAc (1:1), followed by PTLC purification

with petroleum: $\mathrm{CHCl}_{3}: \mathrm{Me}_{2} \mathrm{CO}: \mathrm{MeOH} \quad(4: 8: 1: 2)$ gave $\mathbf{8}(3.12 \mathrm{mg}), \mathbf{2 0}(10.20 \mathrm{mg})$ and $\mathbf{1 7}(3.63$ $\mathrm{mg})$. Further elution of the same fraction with pure $\mathrm{MeOH}$, followed by PTLC purification with petroleum: $\mathrm{CHCl}_{3}: \mathrm{Me}_{2} \mathrm{CO}: \mathrm{MeOH}$ (2:8:1:3) gave 1 (12.08 mg). Elution of R4 with n-hexane:EtOAc $(3: 1)$, followed by PTLC purification with petroleum: $\mathrm{CHCl}_{3}: \mathrm{Me}_{2} \mathrm{CO}: \mathrm{MeOH} \quad(4: 8: 1: 2)$ afforded 16 (17.68 mg). Further elution of R4 with n-hexane:EtOAc (1:1), followed by PTLC purification with petroleum: $\mathrm{CHCl}_{3}: \mathrm{Me}_{2} \mathrm{CO}: \mathrm{MeOH} \quad(4: 8: 1: 2)$ afforded $8(2.05 \mathrm{mg})$ and $20(9.30 \mathrm{mg})$. Further elution of R4 with EtOAc, followed by PTLC purification with petroleum: $\mathrm{CHCl}_{3}: \mathrm{Me}_{2} \mathrm{CO}: \mathrm{MeOH} \quad(2: 8: 1: 3)$ afforded 19 (8.29 mg). Further elution of the same fraction with pure $\mathrm{MeOH}$, followed by PTLC purification with petroleum: $\mathrm{CHCl}_{3}: \mathrm{Me}_{2} \mathrm{CO}: \mathrm{MeOH} \quad(2: 8: 1: 3)$ afforded 1 ( $8.12 \mathrm{mg})$. R5 and R6 were directly subjected to PTLC with running phase petroleum: $\mathrm{CHCl}_{3}: \mathrm{Me}_{2} \mathrm{CO}: \mathrm{MeOH}$ $(2: 8: 1: 3)$ and the alkaloids $20(5.50 \mathrm{mg})$ and $21(6.95 \mathrm{mg})$ were isolated.

1,10-Di-O-methylpakistanine (21): Amorphous solid. UV $\lambda_{\max } \mathrm{nm}(\log \varepsilon): 270 \mathrm{sh}$ 
(4.23), 280 (4.30), 302 (4.10). IR $v_{\max } \mathrm{cm}^{-1}$ : 2858, 2800, 1595. EI MS: $m / z(\%)=636(2)$ $[\mathrm{M}]^{+}, 430$ (10), 340 (6), 324 (15), 296 (5), 206 (100). ${ }^{1} \mathrm{H}$ and ${ }^{13} \mathrm{C}$ NMR in Table 1.

\section{Results and discussion}

The structures of the known alkaloids from the aerial part I: 7, 9, 14, 6, 10, and 1 , earial part II: $1, \mathbf{2}, \mathbf{3}, \mathbf{4}, \mathbf{5}, \mathbf{6}, \mathbf{8}, \mathbf{9}, \mathbf{1 1}, \mathbf{1 2}, \mathbf{1 3}$, 15,16 and 18 , from the roots: $5,18,8,20,17$, 16, 19, and 21 are determined by comparison of its ${ }^{1} \mathrm{H}$ NMR, EI MS, UV and IR data with those of authentic samples (Table 1) $\left[{ }^{6-18}\right]$.

1,10-Di-O-methylpakistanine (21) was reported a natural new alkaloid and the data was reported in the international scientific journal $\left.{ }^{5}\right]$. The MS fragmentation pattern of 1,10-di-O-methylpakistanine (21) was characteristic of an aporphinebenzylisoquinoline dimmer. The weak molecular ion at $\mathrm{m} / \mathrm{z} 636$ was observed in EI MS. The base peak at $\mathrm{m} / z 206$ represented the rings $\mathrm{A}^{\prime}$ and $\mathrm{B}^{\prime}$ in the benzylisoquinoline moiety of the molecule. The peaks at $\mathrm{m} / \mathrm{z} 296$ and $m / z \quad 324$ corresponded to the benzylisoquinoline and aporphine parts of the dimmer, respectively. The fragments at $\mathrm{m} / \mathrm{z}$ $430\left[_{\mathrm{M}-206]^{+}}\right.$and $\mathrm{m} / \mathrm{z} 340[\mathrm{M}-296]^{+}$were also present in the same spectrum. The ${ }^{1} \mathrm{H}$ NMR of 21 exhibited singlets at $\delta 2.50$ and $\delta$ 2.54 for two $\mathrm{NCH}_{3}$ groups, as well as sharp singlets at $\delta 3.64,3.75,3.84,3.85$ and 3.91 for five $\mathrm{OCH}_{3}$ groups. The comparison of ${ }^{1} \mathrm{H}$ NMR data of $\mathbf{2 1}$ with those of 1-Omethylpakistanine (20) showed that spectrum of 21 contained one additional signal at $\delta 3.91$ for one $\mathrm{OCH}_{3}$ group, which is not present in spectrum of 20. In addition, by comparison with ${ }^{1} \mathrm{H}$ NMR spectrum of pakistanine (19), two more $\mathrm{OCH}_{3}$ resonances were observed in ${ }^{1} \mathrm{H}$ NMR spectrum of $21 .{ }^{1} \mathrm{H}$ NMR spectrum of 21 also displayed singlets at $\delta 6.11,6.53$ and 6.71 for four aromatic protons and two doublets at $\delta 6.97$ and $\delta 7.09$ with $J=8.6 \mathrm{~Hz}$ for aromatic protons in ring C'. The most downfield signal in the same spectrum at $\delta$ 8.12 is for the aporphine proton H-11 (Table 2). The described spectral data of $\mathbf{2 1}$ closely resemble those reported for the synthetic alkaloid $\left[{ }^{17}\right]$. The carried out DEPT, NOESY, HMQC and HMBC experiments confirmed the proposal structure of $\mathbf{2 1}$ (Table 2).
Table 1. Alkaloids from Berberis sibirica Pall.

\begin{tabular}{|c|c|c|c|c|}
\hline № & $\begin{array}{l}\text { Name of } \\
\text { alkaloid }\end{array}$ & $\begin{array}{c}\text { Mole- } \\
\text { cular } \\
\text { mass, } \\
\text { weigh } \\
\text { t }\end{array}$ & Structure & $\begin{array}{c}\text { Part } \\
\text { of } \\
\text { plant }\end{array}$ \\
\hline 1 & $\begin{array}{c}\text { Berberine } \\
\mathrm{C}_{20} \mathrm{H}_{18} \mathrm{NO}_{4}\end{array}$ & $\begin{array}{c}336 \\
36.27 \\
\mathrm{mg}\end{array}$ & & $\begin{array}{l}\text { AP I } \\
\text { Root } \\
\text { AP II }\end{array}$ \\
\hline 2 & $\begin{array}{c}\text { Palmatine } \\
\mathrm{C}_{21} \mathrm{H}_{22} \mathrm{NO}_{4}^{+}\end{array}$ & $\begin{array}{c}352 \\
23.85 \\
\mathrm{mgb}\end{array}$ & & AP II \\
\hline 3 & $\begin{array}{c}\text { Columbamin } \\
\mathrm{e} \\
\mathrm{C}_{20} \mathrm{H}_{20} \mathrm{NO}^{+}\end{array}$ & $\begin{array}{c}338 \\
39.5 \\
\mathrm{mg}\end{array}$ & & AP II \\
\hline 4 & $\begin{array}{l}\text { Jatrorrhizine } \\
\mathrm{C}_{20} \mathrm{H}_{20} \mathrm{NO}_{4}^{+}\end{array}$ & $\begin{array}{c}338 \\
11.10 \\
\mathrm{mg}\end{array}$ & & AP II \\
\hline 5 & $\begin{array}{c}8- \\
\text { Oxoberberine } \\
\mathrm{C}_{20} \mathrm{H}_{17} \mathrm{NO}_{5}\end{array}$ & $\begin{array}{c}351 \\
42.5 \\
\mathrm{mg}\end{array}$ & & $\begin{array}{l}\text { AP I } \\
\text { Root } \\
\text { AP II }\end{array}$ \\
\hline 6 & $\begin{array}{c}8- \\
\text { Oxopalmatin } \\
e \\
\mathrm{C}_{21} \mathrm{H}_{21} \mathrm{NO}_{5}\end{array}$ & $\begin{array}{c}367 \\
124.0 \\
\mathrm{mg}\end{array}$ & & $\begin{array}{l}\text { AP I } \\
\text { Root } \\
\text { AP II }\end{array}$ \\
\hline $7 * *$ & $\begin{array}{c}(-)- \\
\text { Tetrahydro- } \\
\text { pseudocoptisi } \\
\text { ne } \\
\mathrm{C}_{19} \mathrm{H}_{17} \mathrm{NO}_{4} \\
\end{array}$ & $\begin{array}{c}323 \\
8.36 \\
\mathrm{mg}\end{array}$ & & AP I \\
\hline $8^{* * *}$ & $\begin{array}{c}(+)- \\
\text { Armepavine } \\
\mathrm{C}_{19} \mathrm{H}_{23} \mathrm{NO}_{3}\end{array}$ & $\begin{array}{c}313 \\
15.02 \\
\mathrm{mg}\end{array}$ & & $\begin{array}{l}\text { AP II } \\
\text { Root }\end{array}$ \\
\hline $9 * *$ & $\begin{array}{l}\text { Pseudoprotop } \\
\text { ine } \\
\mathrm{C}_{20} \mathrm{H}_{19} \mathrm{NO}_{3}\end{array}$ & $\begin{array}{c}353 \\
6.17 \\
\mathrm{mg}\end{array}$ & & $\begin{array}{l}\text { AP I } \\
\text { AP II }\end{array}$ \\
\hline $10^{* *}$ & $\begin{array}{c}(+)- \\
\text { Glaziovine } \\
\mathrm{C}_{18} \mathrm{H}_{19} \mathrm{NO}_{3}\end{array}$ & $\begin{array}{c}297 \\
30.0 \\
\mathrm{mg}\end{array}$ & & AP I \\
\hline 11 & $\begin{array}{l}\text { Pronuciferine } \\
\mathrm{C}_{19} \mathrm{H}_{21} \mathrm{NO}_{3}\end{array}$ & $\begin{array}{c}311 \\
55.07 \\
\mathrm{mg}\end{array}$ & & AP II \\
\hline $12 * *$ & $\begin{array}{c}1-\mathrm{O}- \\
\text { methylisoteb } \\
\text { aidine } \\
\mathrm{C}_{19} \mathrm{H}_{21} \mathrm{NO}_{3}\end{array}$ & $\begin{array}{l}311 \\
8.0 \\
\mathrm{mg}\end{array}$ & & AP II \\
\hline
\end{tabular}




\begin{tabular}{|c|c|c|c|c|}
\hline 13 & $\begin{array}{l}\text { Isocorydine } \\
\mathrm{C}_{20} \mathrm{H}_{23} \mathrm{NO}_{4}\end{array}$ & $\begin{array}{c}341 \\
4.70 \\
\mathrm{mg}\end{array}$ & 1 & AP II \\
\hline $14 * *$ & $\begin{array}{c}(+)- \\
\text { Chelidonine } \\
\mathrm{C}_{20} \mathrm{H}_{18} \mathrm{NbO}_{4}\end{array}$ & $\begin{array}{c}353 \\
25.20 \\
\mathrm{mg}\end{array}$ & & AP I \\
\hline $15^{* *}$ & $\begin{array}{l}\text { Dehydrocory } \\
\text { palline }\end{array}$ & $\begin{array}{c}62.3 \\
\mathrm{mg}\end{array}$ & & AP II \\
\hline 16 & $\begin{array}{l}\text { Pakistanamin } \\
\text { e } \\
\mathrm{C}_{38} \underset{42}{\mathrm{O}} \mathrm{O}_{6} \mathrm{~N}\end{array}$ & $\begin{array}{c}36.58 \\
\mathrm{mg}\end{array}$ & & $\begin{array}{l}\text { AP II } \\
\text { Root }\end{array}$ \\
\hline 17 & $\begin{array}{l}\text { Valdivianine } \\
\mathrm{C}_{37} \mathrm{H}_{40} \mathrm{O}_{6} \mathrm{~N}\end{array}$ & $\begin{array}{r}608 \\
3.63\end{array}$ & & Root \\
\hline $18 * *$ & $\begin{array}{l}\text { Isothalidezin } \\
\begin{array}{r}\mathrm{e} \\
\mathrm{C}_{38} \mathrm{H}_{42} \mathrm{~N}_{2} \mathrm{O}_{7}\end{array}\end{array}$ & $\begin{array}{c}638 \\
4.87 \mathrm{~m} \\
\mathrm{~g}+ \\
14,10 \\
\mathrm{mg} \\
\end{array}$ & & $\begin{array}{l}\text { Root } \\
\text { AP II }\end{array}$ \\
\hline 19 & $\begin{array}{l}\text { Pakistanine } \\
\mathrm{C}_{37} \mathrm{H}_{40} \mathrm{~N}_{2} \mathrm{O}\end{array}$ & $\begin{array}{l}608 \\
8.29\end{array}$ & & Root \\
\hline 20 & 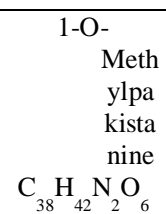 & $\begin{array}{c}622 \\
25.0\end{array}$ & & Root \\
\hline $21 *$ & $\begin{array}{r}1,10 \text {-diO- } \\
\text { Meth } \\
\text { yl- } \\
\text { pakis } \\
\text { tanin } \\
\text { eb } \\
\mathrm{C}_{39} \mathrm{H}_{44} \mathrm{~N}_{2} \mathrm{O}\end{array}$ & $\begin{array}{l}636 \\
6.95\end{array}$ & & Root \\
\hline
\end{tabular}

**-First alkaloid in the family of Berberidaceae

T a b le $2 .{ }^{1} \mathrm{H}$ and ${ }^{13} \mathrm{C}$ NMR data for 1,10 -di-Omethylpakistanine (21)

\begin{tabular}{|c|c|c|}
\hline Position & $\delta \mathrm{H}(\mathrm{J}[\mathrm{Hz}])$ & $\delta \mathrm{C}^{\mathrm{a}}$ and HMQC \\
\hline 1 & $3.75, \mathrm{~s}$ & $145.0, \mathrm{~s}$ \\
\hline $1 \mathrm{a}$ & - & $129.3, \mathrm{~s}$ \\
\hline $1 \mathrm{~b}$ & - & $127.5, \mathrm{~s}$ or $128.6, \mathrm{~s}$ \\
\hline 2 & $3.85, \mathrm{~s}$ & $111.3, \mathrm{~d}$ \\
\hline 3 & $6.53, \mathrm{~s}$ & $128.6, \mathrm{~s}$ or $127.5, \mathrm{~s}$ \\
\hline $3 \mathrm{a}$ & - & $29.3, \mathrm{t}$ \\
\hline 4 & $2.57-2.71, \mathrm{~m}$ & $53.2, \mathrm{t}$ \\
\hline 5 & $2.99-3.07, \mathrm{~m}$ & - \\
\hline 6 & $2.50, \mathrm{~s}$ & $62.4, \mathrm{~d}$ \\
\hline $6 \mathrm{a}$ & $3.81-3.82, \mathrm{~m}$ & $34.5, \mathrm{t}$ \\
\hline 7 & $2.75-2.93, \mathrm{~m}$ & $128.2, \mathrm{~s}$ \\
\hline $7 \mathrm{a}$ & - & $117.3, \mathrm{~d}$ \\
\hline 8 & $6.71, \mathrm{~s}$ & $145.9, \mathrm{~s}$ \\
\hline 9 & - & $155.9, \mathrm{~s}$ \\
\hline 10 & $3.91, \mathrm{~s}$ & $116.6, \mathrm{~d}$ \\
\hline 11 & $8.12, \mathrm{~s}$ & $126.6, \mathrm{~s}$ \\
\hline $11 \mathrm{a}$ & - & $64.8, \mathrm{~d}$ \\
\hline 1 & $3.87-3.88, \mathrm{~m}$ & - \\
\hline 2 & $2.54, \mathrm{~s}$ & $46.8, \mathrm{t}$ \\
\hline 3, & $2.75-2.93, \mathrm{~m} ; 3.14-$ & $24.9, \mathrm{t}$ \\
\hline 4 & $3.30, \mathrm{~m}$ & \\
\hline
\end{tabular}

\begin{tabular}{|c|c|c|}
\hline 4'a & - & $125.7, \mathrm{~s}$ \\
\hline 5 & $6.53, \mathrm{~s}$ & $111.3, \mathrm{~d}$ \\
\hline 6 ' & $3.84, \mathrm{~s}$ & $147.7, \mathrm{~s}$ \\
\hline 7 ' & $3.64, \mathrm{~s}$ & $146.6, \mathrm{~s}$ \\
\hline 8 ' & $6.11, \mathrm{~s}$ & $111.1, \mathrm{~d}$ \\
\hline 8'a & - & $128.6, \mathrm{~s}$ \\
\hline$\alpha^{\prime}$ & $\begin{array}{c}2.75-2.93, \mathrm{~m} ; 3.14- \\
3.30, \mathrm{~m}\end{array}$ & $40.8, \mathrm{t}$ \\
\hline 1, & - & $135.1, \mathrm{~s}$ \\
\hline $2 \%$ & $7.09, \mathrm{~d}(8.6)$ & $131.3, \mathrm{~d}$ \\
\hline 3, & $6.97, \mathrm{~d}(8.6)$ & $118.4, \mathrm{~d}$ \\
\hline $4 "$ & - & $155.1, \mathrm{~s}$ \\
\hline 5, & $6.97, \mathrm{~d}(8.6)$ & $118.4, \mathrm{~d}$ \\
\hline $6 "$ & $7.09, \mathrm{~d}(8.6)$ & $131.3, \mathrm{~d}$ \\
\hline $1-\mathrm{OCH}_{3}$ & - & $60.3, \mathrm{q}$ \\
\hline $2-\mathrm{OCH}_{3}$ & - & $55.9, \mathrm{q}$ \\
\hline $10-\mathrm{OCH}_{3}$ & - & $60.4, \mathrm{q}$ \\
\hline $6^{\prime}-\mathrm{OCH}_{3}$ & - & $55.8, \mathrm{q}$ \\
\hline $7^{\prime}-\mathrm{OCH}_{3}$ & - & $55.7, \mathrm{q}$ \\
\hline 6- $\mathrm{NC}^{-} \mathrm{H}_{3}$ & - & $43.9, \mathrm{q}$ \\
\hline 2'- $-\mathrm{NCH}_{3}$ & - & $42.4, \mathrm{q}$ \\
\hline
\end{tabular}

${ }^{a}$ Multiplicities of the carbon atoms are determined by DEPT experiment

\section{Conclusions}

21 isoquinoline alkaloids were isolated and identified from Berberis sibirica Pall. 1 was a new natural alkaloid and named monpakistanine by us. 8 alkaloids were isolated for the first time in the family of Berberidaceae. High biological active alkaloid berberine, 8-oxopalmatine, 8oxoberberine, pronuciferine and dehydrocorypalline were predominant alkaloids of Berberis sibirica ant and it is showing a proof that this plant is being used widely in Mongolian traditional medicine.

\section{Acknowledgements}

Thank for found of Science and Technology of Mongolia and Science and Technology of Bulgaria.

\section{References}

1. SCHNEIDER G.

Pharmazeutische

Mannheim/ Wien/ Zürich,

Bibliographisches Institut, 2, 419-420.

2. PetKov V. (Ed.). (1982) Modern Phytotherapy, Sofia, Medicina and Fizkultura, 207-208.

3. Shamma M., J. L. Moniot. (1978) Isoquinoline Alkaloids Research 1972-1978, New York and London, Plenium Press, 249-251.

4. LigaA U. (1996) Medicinal plants of Mongolia used in Mongolian 
traditional medicine, Korea, Seoul, 202.

5. Istatkova R., S.Philipov, P.Tuleva, A.Solongo, S.Javzan, D.Selenge (2007) Compt.rend. Acad. Bulg. Sci., 60, №11, 1177-1182.

6. OHIRI F. C., R. Verpoorte, A. SVENDSEN. (1983) Planta Medica, 49, 162-164.

7. Johns S. R., J. A. LAmberton, H. J. TwEEDDALE, R. I. WILLING. (1969) Aust. J. Chem., 22, 2233-2236.

8. SHAMma M. (1972) The Isoquinoline Alkaloids, New York and London, Academic Press, 81-83; 335, 341.

9. NinOMIYA I., T. NAITO, H. TAKASUGI. J. (1975) Chem. Soc. Perkin I, 17201724.

10. Stuart K. L., M. P. Cava. (1968) Chemical Reviews, 68, 321-339.

11. HABERMEHL G., J. SCHUNK, G. SCHADEN. (1970) Liebigs Ann. Chem., 742, 138-144.
12. $\left[{ }^{12}\right]$ JANSSEN R. H. A. M., R. J. J. LOUSBERG, P. WiJKens, C. KRUK, H. G. Theuns. (1989) Phytochemistry, 28, 2833-2839.

13. Miana G. (1973) Phytochemistry, 12, 1822-1823.

14. GuHA K. P., B. Mukherjee, R. MuKHERJEE. (1979) J. Nat. Prod., 42, 1-84.

15. HuSSiAn S. F., L. KHAN, K. KHAN, M. Shamma. (1981) J. Nat. Prod., 44, 274-278.

16. Fajardo V., F. Podestá, A. Urzúa (1986) Rev. Latinoamer. Quim., 16, 141-156.

17. ShAMmA M., J. L. MONIOT, S. Y. YAO, G. A. MiANA, M. IKRAM (1973) J. Amer. Chem. Soc., 95, 5742-5747.

18. Guinadeau H., M. Leboeuf, A. CAVÉ (1bb979) J. Nat. Prod., 42, 133149. 